\title{
Role of FSH, numbers of FSH receptors and testosterone in the regulation of inhibin secretion during the seasonal testicular cycle of adult rams
}

\author{
L. M. Sanford ${ }^{1 *}$, C. A. Price ${ }^{2}$, D. G. Leggee ${ }^{1 \dagger}$, S. J. Baker ${ }^{1 \neq}$ \\ and T. A. Yarney ${ }^{3}$, \\ ${ }^{1}$ Department of Animal Science, McGill University, Macdonald Campus, Ste Anne de \\ Bellevue, Québec H9X 3V9, Canada; ${ }^{2}$ Centre de Recherche en Reproduction Animale, \\ Faculté de Médecine Vétérinaire, Université de Montréal, St-Hyacinthe, Québec J2S 7C6, \\ Canada; and ${ }^{3}$ Reproduction Research Laboratory, Clinical Research Institute of Montreal, \\ Montréal, Québec H2W 1R7, Canada
}

The regulation of inhibin secretion has not been elucidated fully in male ruminants. The aim of this study was to determine the relative importance of FSH and testosterone concentrations, and $\mathrm{FSH}$ receptors, in the control of secretion of immunoactive inhibin in rams. In Expt 1, temporal changes in hormone concentrations and testicular FSH binding were determined for two groups of rams $(n=4)$ kept under opposite, alternating 4 month periods of long (16 $\mathrm{h}$ light: $8 \mathrm{~h}$ dark) and short (8 $\mathrm{h}$ light:16 $\mathrm{h}$ dark) days. Testicular biopsies (1-2 g) were collected when the testes were regressed, redeveloping, redeveloped and regressing. In Expt 2, separate groups of rams $(n=4)$ kept under natural photoperiod (latitude $45^{\circ} 48^{\prime} \mathrm{N}$ ) were designated as controls or passively immunized (for 3 weeks) with sufficient oestradiol antiserum to increase testosterone secretion without altering $\mathrm{LH}$ and $\mathrm{FSH}$; this was done when the testes were regressed (non-breeding season) and redeveloped (breeding season). In both groups of rams (Expt 1), 'seasonal' increases in FSH concentrations began a few weeks earlier than did increases in inhibin concentrations. FSH reached maximum concentrations during testicular recrudescence, whereas numbers of FSH receptors in the testis and circulatory inhibin concentrations did not reach peak values until the testes were fully developed. Numbers of FSH receptors per testis, but not FSH concentration, were positively correlated $(r=0.65)$ with inhibin concentrations across the four stages of the testicular cycle. Near the end of testicular recrudescence early in the breeding season (Expt 2), relatively high FSH concentration was associated with increased abundance of FSH receptor mRNA $(90 \%)$ and number of receptors $(45 \%)$ in the testis and increased inhibin concentrations $(50 \%)$, compared with when the testes were regressed. Moderate, physiological increases in testosterone secretion in immunized rams did not affect inhibin in either season. These results indicate that: (i) FSH stimulation of immunoactive inhibin secretion by Sertoli cells as testes recrudesce is via increases in secretion (early) and cognate receptors (late); (ii) $\mathrm{FSH}$ upregulates the synthesis of its own receptor late in recrudescence; and (iii) the positive correlation $(r=0.70)$ observed between circulatory testosterone and immunoactive inhibin does not reflect a causal relationship.

\section{Introduction}

Inhibin is a heterodimeric glycoprotein named for its regulatory effect on FSH synthesis and secretion. It consists of an $\alpha$-subunit and one of two related $\beta$-subunits $\left(\beta_{\mathrm{A}}\right.$ and

\footnotetext{
*Address for correspondence: 111 Bruce Street, Suite 616, Kirkland, Québec H9H 4B7, Canada

'Present address: Centre for Indigenous Peoples' Nutrition and Environment, McGill University, Macdonald Campus, Ste Anne de Bellevue, Québec H9X 3V9, Canada

FPresent address: 4 McKenzie, Senneville, Québec H9X 3M3, Canada

Email: LSanford@total.net
}

$\beta_{B}$ ) (Gnessi et al., 1997). A dimeric ovine inhibin of about $32 \mathrm{kDa}$ has been isolated from rete testis fluid of adult rams and the N-terminal sequence of its subunits has been characterized (Vale et al., 1988; Bardin et al., 1989). The inhibin $A\left(\alpha \beta_{A}\right)$ form was identified, but not inhibin $B\left(\alpha \beta_{B}\right)$, indicating that inhibin $A$ may be the predominant dimer produced in the testis and present in peripheral blood of rams. In male primates (Illingworth et al., 1996; Plant et al., 1997) and rodents (Woodruff et al., 1996; Abel et al., 2000; Jin et al., 2001), inhibin B is known or believed to be the primary dimeric form in the blood circulation. Inhibin concentration in rams is increased in late fetal life (Phillips et al., 1992; Miller et al., 1997) and in the first few months after birth (Schanbacher, 1988; Sanford et al., 2000) when 
Sertoli cells are completing proliferation (Hochereau-de Reviers et al., 1987). A comparatively small increase in inhibin occurs in mature rams during seasonal testicular recrudescence (Sanford et al., 2000). Inhibin is involved in suppression of FSH secretion in late fetal life (Miller et al., 1997), during puberty (Al-Obaidi et al., 1987; Tilbrook et al., 1999a) and in adulthood (McKeown et al., 1997; Tilbrook et al., 1999b). Furthermore, dimeric inhibin and forms of the $\alpha$-subunit of inhibin may act as paracrine/ autocrine regulators in the testis (Schneyer et al., 1991; Gnessi et al., 1997; Chong et al., 2000).

Most of the inhibin in the blood pool comes from the gonad (Schanbacher, 1988; Miller et al., 1997; Tilbrook et al., 1999a) and the Sertoli cells in particular. Sertoli cells in the testes of ram fetuses appear to express all three inhibin subunits $\left(\alpha, \beta_{\mathrm{A}}\right.$ and $\left.\beta_{\mathrm{B}}\right)$ (Thomas et al., 1995; Jarred et al., 1999), as do Leydig cells until day 90 of fetal development when the $\alpha$-subunit is no longer detectable (Jarred et al., 1999). This is consistent with the finding that Leydig cells in adult rams do not secrete inhibin in response to hCG or endogenous LH (Tilbrook et al., 1991). FSH is a primary regulator of inhibin secretion by Sertoli cells, stimulating synthesis of the $\alpha$-subunit, which is produced in excess to the $\beta$-subunit (Bardin et al., 1989; Steinberger et al., 1992). In rams, FSH administration increases inhibin production by fetal testis (Albers et al., 1989) and the output of inhibin into the testicular lymphatic and vascular systems in adults (Voglmayr et al., 1992). Corresponding increases in FSH, immunoactive inhibin (Lincoln and McNeilly, 1989; Sanford et al., 1993) and inhibin A (Lincoln et al., 2001) during testicular redevelopment, and greater numbers of $\mathrm{FSH}$ receptors in the testis in the breeding season compared with the non-breeding season (Barenton and Pelletier, 1983; Monet-Kuntz et al., 1988), provide additional evidence for $\mathrm{FSH}$ regulation of inhibin secretion in rams. However, the mode of FSH action (altered secretion versus number of receptors) and the regulation of gene expression for $\mathrm{FSH}$ receptors as testes pass through the different stages of the seasonal cycle are poorly understood. In the present study, experiments were designed to clarify the temporal relationship between $\mathrm{FSH}$ and inhibin concentrations, and the number of FSH receptors across specific stages of the testicular cycle. In particular, the hypotheses that changes in $\mathrm{FSH}$ receptors as well as FSH concentrations are responsible for changes in inhibin secretion, and that $\mathrm{FSH}$ modulates the synthesis of its cognate receptor, were tested.

Inhibin secretion by Sertoli cells may also be regulated by paracrine mechanisms acting within the testis. Sertoli cells in rodent species and human males have androgen receptors, and normal cell function requires both testosterone and FSH (Sar et al., 1993). Thus, testosterone from neighbouring Leydig cells is a candidate for inhibin regulation. An effect of testosterone may also be mediated indirectly by other androgen target cells such as peritubular myoid cells. Rat peritubular cells secrete a non-mitogenic paracrine factor, PmodS, in response to testosterone, which stimulates the secretion of a number of Sertoli cell proteins, including inhibin (Gnessi et al., 1997). Other studies, mainly with Sertoli cells in culture, give conflicting indications as to whether testosterone stimulates or inhibits inhibin secretion (Bardin et al., 1989; Risbridger and de Kretser, 1989). Sertoli cells and peritubular cells in ram testis contain androgen receptors (Lincoln et al., 1996), and seasonal variations in blood inhibin and testosterone concentrations are positively correlated (Lincoln and McNeilly, 1989; Sanford et al., 1993). The possibility that there is a causal relationship between these two hormones has not been examined. This aspect of paracrine regulation of inhibin secretion was investigated in the present study in a novel experimental model using oestradiol immunoneutralization. In this model, testosterone secretion in rams is increased without increasing $\mathrm{LH}$ and $\mathrm{FSH}$ stimulation to the testes (Sanford, 1987, 1989; Sanford et al., 1991). The hypothesis that this increased testosterone production would alter inhibin secretion from the testis was tested.

\section{Materials and Methods}

\section{Animals}

Adult DLS (Dorset-Leicester-Suffolk) rams $(n=24)$ were used in this investigation. Rams of the relatively new DLS breed of sheep show moderate changes in most of their reproductive endocrine traits during the seasonal testicular cycle (Sanford and Robaire, 1990; Sanford et al., 1993). Animals were provided from the Agriculture and Agri-Food Canada research flock in La Pocatière, Québec. They were fed a diet of hay and grain, and had free access to a mineralvitamin mixture and drinking water. Animal experimentation was done in accordance with guidelines of the Canadian Council on Animal Care and the Animal Care Committee of McGill University.

\section{Experimental protocols}

In Expt 1, four rams were placed in each of two adjacent photoperiod-controlled rooms measuring $3 \mathrm{~m} \times 3 \mathrm{~m}$. The rams were subjected to alternating 4 month periods of stimulating ( $8 \mathrm{~h}$ light: $6 \mathrm{~h}$ dark) and inhibiting (16 h light:8 h dark) daylengths, beginning with either short days (group 1 rams) or long days (group 2 rams). Light intensity in the centre of the rooms at the head level of the rams was 90 lux. After the testicular cycle of rams was entrained to the prevailing photoperiods in the initial 12 months, scrotal circumference and blood hormone concentrations (testosterone, inhibin and $\mathrm{FSH}$ ) were determined at frequent intervals for the next 14 months. Rams were 30-months-old and weighed $74.6 \pm 3.0 \mathrm{~kg}$ at the onset of the experimental period, which was equivalent to nearly two 'seasonal' testicular cycles. Body weight of the rams increased $(P<0.01)$ by $15 \%$ during the first 7 months, but remained stable thereafter when testicular biopsies were taken in regressed, redeveloping, redeveloped and regressing stages of the testicular cycle to assess FSH receptor binding activity.

In Expt 2, separate groups of four rams (aged 6 years) kept 
indoors, but exposed to natural changes in photoperiod (latitude $45^{\circ} 48^{\prime} \mathrm{N}$ ), were passively immunized against oestradiol for 3 weeks beginning in mid-August or midMarch. Other groups of four rams served as controls. Blood samples were collected for hormonal analyses (testosterone, inhibin and $\mathrm{FSH}$ ) on day 21 of immunization and, on day 23, rams were gonadectomized and testicular tissue was collected to assess FSH receptor binding activity and mRNA abundance. Collections were made when testicular size and testosterone secretion in adult DLS rams are normally near or at yearly high and yearly low values (Sanford and Robaire, 1990; Paquette, 1993), and when adult DLS ewes are showing oestrous activity or becoming seasonally anoestrous (Fahmy and Shrestha, 1992). Body weight of rams, recorded at the time of gonadectomy, was $20 \%$ higher $(P<0.01)$ in the breeding season $(90.9 \pm 2.4 \mathrm{~kg})$ than in the non-breeding season $(75.7 \pm 3.5 \mathrm{~kg})$. The testosterone results presented in this study have been reported elsewhere (Price et al., 2000).

\section{Passive immunization against oestradiol}

The antiserum used in passive immunization (Expt 2) was raised in gonadectomized, adult DLS rams against oestradiol-6-(0-carboxymethyl)oxime-BSA. Active immunization procedures and preparation of antisera harvested for use in the present study are described elsewhere (Sanford, 1987; Squire et al., 1993). The pool of antiserum prepared had a titre of 1:4500 and was specific for oestradiol; it crossreacted only slightly with oestrone (15\%). Passively immunized rams were injected (jugular vein) with $60 \mathrm{ml}$ oestradiol antiserum every 3 or 4 days for 3 weeks (total of seven injections). In the breeding season, the amount was increased to $120 \mathrm{ml}$ in week 2 to take into account the $50-100 \%$ higher oestradiol concentration in peripheral blood of DLS rams when testes are in the redeveloped state (Sanford et al., 1993). This immunization protocol was used to produce an antibody titre in rams of about 1:200 within a week or so, and an LH-independent increase in testosterone secretion by week 3 (Sanford, 1987, 1989; Sanford et al., 1991).

\section{Blood sampling and hormone assays}

Blood samples were collected serially from rams on 17 occasions during the 14 month experimental period in Expt 1 and on one occasion at the end of the immunization period in Expt 2. A sample of blood $(7 \mathrm{ml})$ was withdrawn from the jugular vein by venepuncture every $20 \mathrm{~min}$ for either $6 \mathrm{~h}$ (Expt 1) or $8 \mathrm{~h}$ (Expt 2), beginning at about 09:30 h. Mean hormone concentrations were determined by assaying serum pools (equal aliquots of 18 or 25 sera) representing individual rams and sampling periods, with one exception. In Expt 2, mean and basal (interpulse) testosterone concentrations were determined by averaging values of all individual sera or only the lowest values not associated with testosterone pulses, defined as described by Sanford et al. (1993).
Double-antibody radioimmunoassay procedures were used to determine serum testosterone (Sanford, 1985) and FSH (Cheng et al., 1981) concentrations. The reference preparation in the $\mathrm{FSH}$ assay was NIH-FSH-S12. Minimum detectable concentrations of testosterone and $\mathrm{FSH}$ at the serum volumes indicated were $0.20 \mathrm{ng} \mathrm{ml}^{-1}(50 \mu \mathrm{l})$ and $2.2 \mathrm{ng} \mathrm{ml}^{-1}(100 \mu \mathrm{l})$, respectively. Immunoactive inhibin concentration was measured using the double-antibody radioimmunoassay procedure developed by Vaughan et al. (1989). The primary antiserum was raised in a rabbit against a synthetic peptide fragment of porcine inhibin $\alpha$-subunit (1-26 AA sequence of the $\mathrm{N}$-terminus). The assay used human inhibin $\alpha 1-25$ subunit as tracer and ovine inhibin $\alpha$ 1-25 subunit as the reference preparation. The primary antibody detects forms of the free $\alpha$-subunit of inhibin, as well as dimeric inhibin; however, measures of inhibin using antisera generated against the synthetic porcine inhibin $\alpha$ subunit fragment increase in parallel to specific measures of dimeric inhibin A during testicular recrudescence (Lincoln and McNeilly, 1989; Lincoln et al., 2001). Unknown values have been expressed as pmol $32 \mathrm{kDa}$ inhibin $\mathrm{ml}^{-1}$. Minimum detectable concentration was $0.30 \mathrm{pmol} \mathrm{ml^{-1 }}$ $(50 \mu \mathrm{l})$. Intra- and interassay coefficients of variation in these procedures were all $<12 \%$.

\section{Collection of testicular tissue}

Testicular biopsies were taken from rams (Expt 1) as described by Sanford (1989). Between $1 \mathrm{~g}$ and $2 \mathrm{~g}$ of tissue was excised after a $2-3 \mathrm{~cm}$ incision was made into the midregion of the scrotal sac and underlying layers of the testicular capsule. Tissue samples were frozen in liquid nitrogen and stored at $-70^{\circ} \mathrm{C}$ until analysed for $\mathrm{FSH}$ receptor binding activity. Gonadectomy of rams (Expt 2) was as reported by Price et al. (2000). After the testes were removed from rams and weighed, 1-2 g samples of testicular tissue were taken to determine $\mathrm{FSH}$ receptor binding activity and mRNA abundance. Tissue for RNA extraction was placed immediately into 4 mol guanidinium isothiocyanate $\mathrm{I}^{-1}$ containing $0.12 \mathrm{~mol} \beta$-mercaptoethanol $\mathrm{I}^{-1}$. All samples were frozen on dry ice and stored at $-70^{\circ} \mathrm{C}$.

\section{FSH receptor binding assay}

Established procedures (Yarney et al., 1988) were used to determine $\mathrm{FSH}$ receptor binding activity in the testis. Methods for membrane extraction, radioiodination of $\mathrm{FSH}$ and assay of FSH receptors were modified slightly in Expt 2. Pieces of testicular tissue were homogenized in cold 25 mmol Tris- $\mathrm{HCl}$ (pH 7.2) $\mathrm{I}^{-1}$ buffer containing $250 \mathrm{mmol}$ sucrose $\mathrm{I}^{-1}, 100 \mu \mathrm{g}$ bacitracin $\mathrm{ml}^{-1}$ (Sigma, St Louis, MO) and $1 \mathrm{mmol}$ phenylmethane sulphonyl fluoride (PMSF) $\mathrm{I}^{-1}$ (Sigma). Tissue homogenates were centrifuged at $500 \mathrm{~g}$ for $30 \mathrm{~min}$, followed by centrifugation of supernatant at $30000 \mathrm{~g}$ for $30 \mathrm{~min}$ to recover membrane fractions. The membrane pellets were washed and resuspended in 25 mmol Tris- $-\mathrm{HCl} \mathrm{I}^{-1}$ buffer $(\mathrm{pH} 7.2)$ containing $0.2 \%(\mathrm{w} / \mathrm{v})$ $\mathrm{MgCl}_{2}$ and PMSF. Membranes were snap frozen in liquid 
nitrogen and stored at $-70^{\circ} \mathrm{C}$ until assayed. For the assay, highly purified human FSH (Sairam et al., 1978) was labelled with ${ }^{125}$ I (lodoGen; Pierce Chemical Co., Rockford, IL). Radiolabelled FSH was purified on Bio-Rad Bio-Gel P-6 gel desalting columns (Bio-Rad, Richmond, CA). Single point binding assays were carried out in duplicate in assay buffer (25 mmol Tris- $\mathrm{HCl} \mathrm{I-1,} \mathrm{pH} 7.2,0.2 \%(\mathrm{w} / \mathrm{v}) \mathrm{MgCl}_{2}$, $0.1 \%(\mathrm{w} / \mathrm{v}) \mathrm{BSA})$ with near saturating concentration of radiolabelled hormone (5 ng). In both experiments, the specific activity of labelled $\mathrm{FSH}$ ranged from 54 to $75 \mu \mathrm{Ci}$ ( $\mu$ g hormone) $)^{-1}(1 \mathrm{Ci}=37 \mathrm{GBq})$. The biologically active fraction, determined by the percentage binding of labelled FSH to excess pig or sheep testicular membranes, was 28-39\%. Non-specific binding in the presence of $1 \mu \mathrm{g}$ unlabelled ovine FSH was $<20 \%$ of total binding. Intra- and interassay coefficients of variation were $<12 \%$.

Membrane protein content was determined by the BioRad assay (Bio-Rad) in Expt 1 and by the bicinchoninic acid method (Smith et al., 1985) in Expt 2, with reagents supplied by Pierce Chemical Co. Protein estimates were 30\% lower using the latter method. Aliquots of membrane fractions were first solubilized by boiling for $30 \mathrm{~min}$ in 0.5 or $1.0 \mathrm{~mol}$ $\mathrm{NaOH} \mathrm{I}{ }^{-1}$ and assayed after neutralization with $\mathrm{HCl}$. BSA was used as a standard.

The amount of membrane-bound $\mathrm{FSH}$, taken to reflect the number of unoccupied FSH receptors, was determined in the equivalent of $25 \mathrm{mg}$ wet tissue. Binding activity was assessed on a per mg membrane protein, per g tissue and per testis basis.

\section{FSH receptor $m R N A$ analysis}

Testicular tissue (Expt 2) was thawed and homogenized in 4 mol guanidium isothiocyanate $\mathrm{I}^{-1}$ containing $0.12 \mathrm{~mol}$ $\beta$-mercaptoethanol $\mathrm{I}^{-1}$. Total RNA was isolated by centrifugation for $21 \mathrm{~h}$ at $174000 \mathrm{~g}$ on a cushion of $5.7 \mathrm{~mol}$ caesium chloride $\mathrm{I}^{-1}$. The pellet was resuspended in $3 \mathrm{~mol}$ sodium acetate $\mathrm{I}^{-1}$, precipitated twice with ethanol and quantified by measuring absorbance at $260 \mathrm{~nm}$.

Total RNA was analysed by slot blot hybridization (6 $\mu \mathrm{g})$ as described by Sambrook et al. (1989) and membranes were cross-linked $(150 \mathrm{~mJ})$ in a commercial UV chamber (Bio-Rad, Mississauga, ON). The membranes were incubated for $2 \mathrm{~h}$ in prehybridization solution containing $10 \%$ (w/v) dextran sulphate, 5-strength saline-sodium phosphateEDTA (SPPE), 5-strength Denhardt's solution, 0.5\% (w/v) sodium dodecyl sulphate (SDS) and herring sperm DNA (200 mg m-1 $\mathrm{m}^{-1}$. Hybridization with a labelled bovine cDNA probe was performed at $65^{\circ} \mathrm{C}$ overnight. After hybridization, membranes were washed twice in double strength SSPE- $0.1 \%(\mathrm{w} / \mathrm{v})$ SDS at room temperature and twice at $65^{\circ} \mathrm{C}$. The labelled membranes were exposed to Kodak XOmat film (Kodak Canada Inc., Toronto, ON) at $-70^{\circ} \mathrm{C}$ in the presence of an intensifying screen for 1-5 days. The membranes were stripped and rehybridized to a labelled $28 \mathrm{~S}$ ribosomal cDNA probe as an internal control. Relative abundance of signal was quantified by densitometry
(Collage Analysis; Fotodyne Inc., Hartland, WI). The density of hybridization signals was corrected for loading using hybridization to $28 \mathrm{~S}$ and these corrected data were expressed relative to a control ram sample that was included in the two blots.

The bovine FSH receptor cDNA probe was a $1264 \mathrm{bp}$ fragment generated by $\mathrm{RT}-\mathrm{PCR}$, representing a portion of the extracellular binding domain to the $3^{\prime}$ stop codon (Houde et al., 1994). The probe was labelled with $\left[\alpha^{32} \mathrm{P}\right]$ dCTP by random primer extension (T7 Quickprime; Pharmacia, Dorval, QC) and was purified by centrifugation through a minicolumn using Wizard PCR Prep DNA purification (Promega, Ottawa, ON).

\section{Data analyses}

In Expt 1, scrotal circumference was recorded approximately every 2 weeks during the 8 month 'seasonal' testicular cycles. Only values corresponding closely to the days of blood collection are presented. Paired-testes mass at the time of testicular biopsy was estimated from measurement of scrotal circumference using a regression equation reported by Knight (1977) for Romney rams ( $r=0.93$, $n=25)$ with similar measurements (range 27-36 cm). Weight estimates were used to determine relative differences in $\mathrm{FSH}$ receptor binding on a per gram of tissue and per testis basis between stages of the testicular cycle. Mean hormone concentrations at the time of biopsy were derived by extrapolation from concentrations determined for the period of blood sampling just before and afterwards.

All data from Expt 1 were subjected to ANOVA for repeated measures (SAS, 1989). The significance of month (within group) was determined by one-way ANOVA and of group and stage of testis cycle by two-way ANOVA. Twoway ANOVA was also used to determine differences in maximum values for scrotal circumference and hormone concentrations between groups and 8 month 'seasonal' cycles. When the main effect of time (month, stage, cycle) or the group $\times$ time interaction was significant $(P<0.05)$, comparisons of least-squares means were made using the PDIFF (probability difference) test. Where appropriate, a logarithmic transformation was applied in these analyses to normalize variances. Linear regression analysis was used to determine relationships between testicular size or serum concentration of immunoactive inhibin and selected endocrine variables. Pearson correlation coefficients were calculated for each group, either by pooling $r$ values obtained on individual rams across months of their 'seasonal' cycles or on combined data for the four rams across stages of their testicular cycles. Correlations on individual rams were tested for homogeneity before pooling (Steel and Torrie, 1960). Non-homogeneity appeared only once (group 1, inhibin and previous FSH) and in this instance, the pooled $r$ value represents three rather than four animals.

In Expt 2, two-way ANOVA was used to determine the significance of season and immunization (SAS, 1989). 

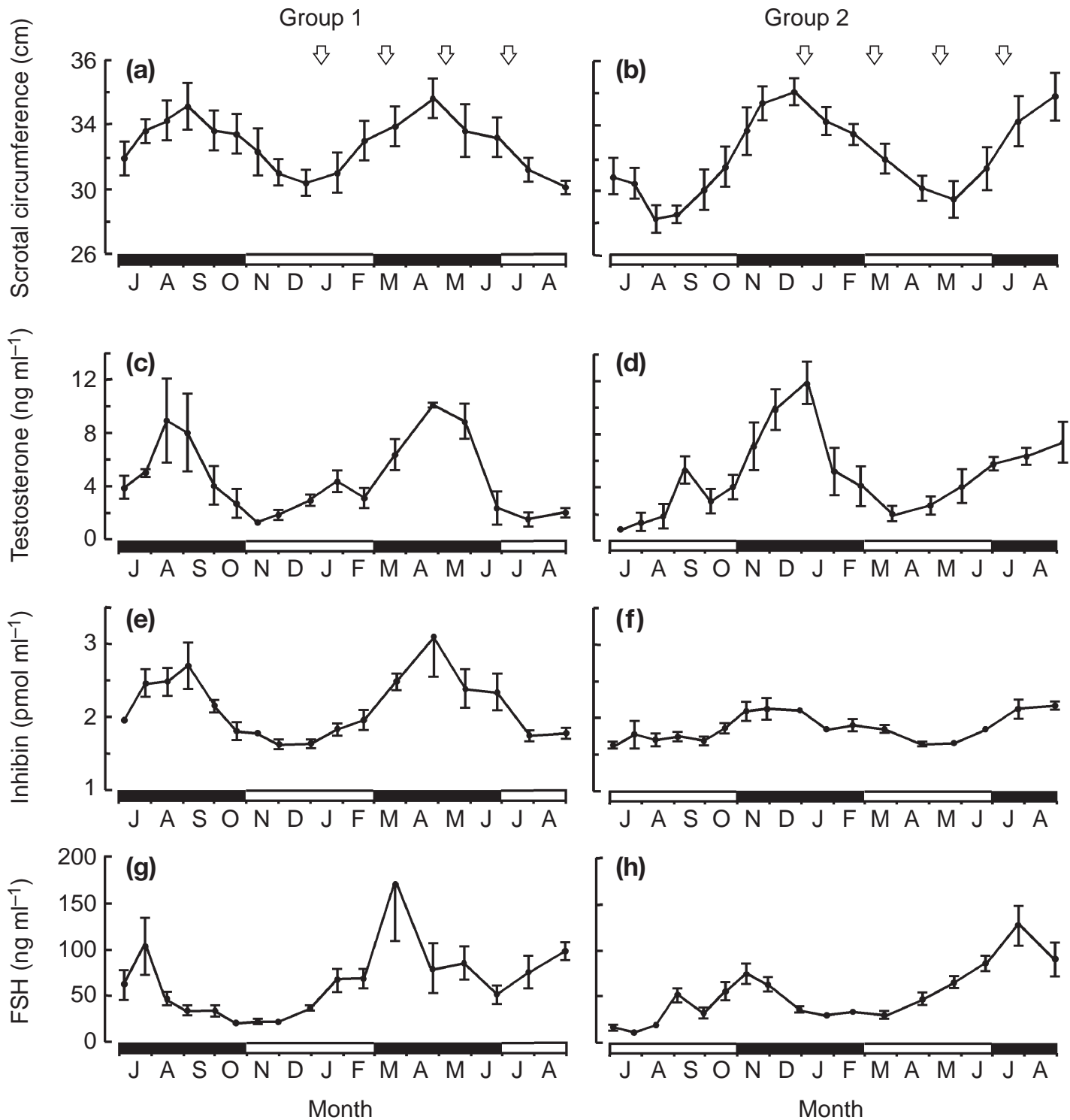

Fig. 1. $(a, b)$ Scrotal circumference and mean serum concentrations of $(c, d)$ testosterone, $(e, f)$ immunoactive inhibin and (g,h) FSH for group $1(\mathrm{a}, \mathrm{c}, \mathrm{e}, \mathrm{g})$ and group $2(\mathrm{~b}, \mathrm{~d}, \mathrm{f}, \mathrm{h})$ rams during alternating 4 month periods of stimulative ( $8 \mathrm{~h}$ light :16 h dark, $\mathbf{0})$ and inhibitive (16 h light: $8 \mathrm{~h}$ dark, $\square)$ daylength. Values are mean $\pm \operatorname{SEM}(n=$ 4 rams). Arrows $(a, b)$ indicate times of testicular biopsy when testes were regressed, redeveloping, redeveloped and regressing.

When main effects or the season $\times$ immunization interaction were significant $(P<0.05)$, least-squares means were compared by the PDIFF test. If necessary, data were first transformed to logarithms. Pearson correlation coefficients were calculated for select pairs of endocrine variables using data on all four groups of rams. One of the control rams (non-breeding season) had such an abnormally high LH release (Price et al., 2000) and, to a lesser extent, FSH secretion, that the data for this ram were excluded from these analyses.

\section{Results}

\section{Experiment 1}

Scrotal circumference of rams increased $(P<0.01)$ by about $6 \mathrm{~cm}$ between mid-long days and mid-short days to maximal values that were similar between groups and 'seasonal' testicular cycles (Fig. 1a,b). Mean testosterone concentration increased similarly in rams of both groups during testicular recrudescence; highest concentrations in mid-short days were several-fold greater $(P<0.01)$ than the 
Table 1. Correlations between scrotal circumference or serum immunoactive inhibin concentration and selected endocrine variables for group 1 and group 2 rams across the months of their 8 month 'seasonal' testicular cycles

\begin{tabular}{cccccccc}
\hline & \multicolumn{2}{c}{ Scrotal circumference } & & \multicolumn{3}{c}{ Inhibin } \\
\cline { 2 - 3 } & Inhibin & $\mathrm{FSH}^{1}$ & $\mathrm{FSH}^{2}$ & & Testosterone & $\mathrm{FSH}^{1}$ & $\mathrm{FSH}^{2}$ \\
\hline Group 1 & $0.73^{* *}$ & $0.26^{*}$ & $0.46^{* *}$ & & $0.69^{* *}$ & $0.30^{*}$ & $0.71^{* *}$ \\
Group 2 & $0.72^{* *}$ & $0.32^{*}$ & $0.65^{* *}$ & & $0.65^{* *}$ & $0.42^{* *}$ & $0.64^{* *}$ \\
\hline
\end{tabular}

$\mathrm{FSH}^{1}$ : corresponding mean concentration; $\mathrm{FSH}^{2}$ : mean concentration about 4 weeks earlier.

${ }^{*} P<0.05$ and ${ }^{* *} P<0.01$ with $52\left(\mathrm{FSH}^{2}\right)$ or 60 (other variables) error $\mathrm{df}$, except for group 1 inhibin and $\mathrm{FSH}^{2}$ with 39 error $\mathrm{df}$.

lowest concentrations early in long days (Fig. 1c,d). Fluctuations in mean inhibin concentration were fairly moderate with highest concentrations in mid-short days only $75 \%$ (group 1, Fig. 1e) or 30\% (group 2, Fig. 1f) higher $(P<0.01$ ) than the lowest concentrations in the first or second month of long days. Inhibin peaks were lower $(P<0.05)$ in group 2 rams than in group 1 rams during both 'seasonal' cycles. Maximal mean FSH concentrations occurred relatively early in short days and were several-fold higher $(P<0.05)$ than minimal concentrations early in long days (Fig. 1g,h). There were no differences in peak FSH concentrations between groups or 'seasonal' cycles. For both groups, variations in inhibin concentration during the 14 month experimental period were related to variations in scrotal circumference and testosterone concentration $(r=0.65-0.73$, $P<0.01$ ) (Table 1). Inhibin concentration and scrotal circumference changed in relation to $\mathrm{FSH}$, more noticeably with concentrations about 4 weeks earlier $(r=0.46-0.71$, $P<0.01)$ than with those concurrent $(r=0.26-0.42$, $P<0.05)$.

The first in a series of four testicular biopsies was taken early in month 7 when testes were either regressed under long days (group 1, Fig. 1a) or redeveloped under short days (group 2, Fig. 1b). Subsequent biopsies taken 2 months apart clearly coincided with the remaining three stages of the testicular cycle in each group. Irrespective of when in the testicular cycle biopsy began, scrotal circumference was similar for rams of both groups in each stage, averaging $30.3 \pm 0.7 \mathrm{~cm} \quad(n=8)$ in the regressed stage and $35.4 \pm 0.9 \mathrm{~cm}$ in the redeveloped stage. Larger scrotal circumference measurements with testicular redevelopment corresponded to an increase $(P<0.01)$ in estimated testicular mass of $40 \%$ (Fig. 2a). Mean testosterone concentration was threefold higher $(P<0.01)$ when testes were redeveloped than regressed. Unlike testicular mass, testosterone concentration decreased to regressed rather than intermediate values in the regressing stage (Fig. 2b).

In group 1 rams, mean inhibin concentration was successively higher $(P<0.05)$ in the redeveloping $(25 \%)$ and redeveloped $(70 \%)$ stages of the testicular cycle compared with the regressed stage (Fig. 2c). Corresponding increases in inhibin in group 2 rams were considerably
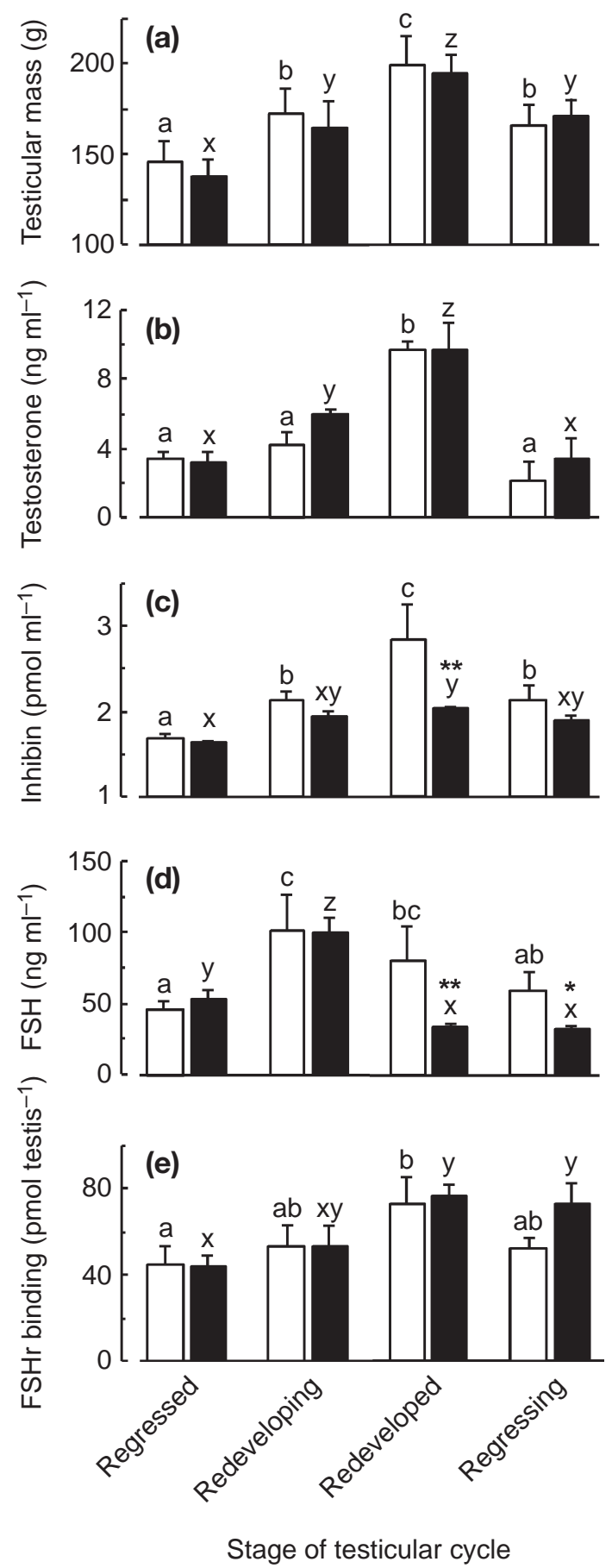

Fig. 2. Estimated (a) testicular mass, mean serum concentrations of (b) testosterone, (c) immunoactive inhibin and (d) FSH, and (e) FSH receptor $(\mathrm{FSHr}$ ) binding per testis for group $1(\square)$ and group 2 ( $\square$ ) rams during the regressed, redeveloping, redeveloped and regressing stages of their 'seasonal' testicular cycles. Values are mean $\pm \operatorname{SEM}(n=4$ rams). Within groups, bars with different letters ${ }^{(\mathrm{a}-\mathrm{c}}$ or $\left.{ }^{\mathrm{x}-\mathrm{z}}\right)$ are significantly different $(P<0.05)$. Asterisks indicate significant $\left(* P<0.05\right.$ or $\left.{ }^{* *} P<0.01\right)$ differences between groups.

lower such that mean concentration in the developed stage was $40 \%$ lower $(P<0.01)$ than that for group 1 rams. Mean FSH concentration was highest in both groups in the 
Table 2. Correlations $(r)$ between estimated testicular mass or serum immunoactive inhibin concentration and selected endocrine variables for group 1 and group 2 rams across the four stages of their 'seasonal' testicular cycles

\begin{tabular}{|c|c|c|c|c|c|c|}
\hline & \multicolumn{3}{|c|}{ Testicular mass } & \multicolumn{3}{|c|}{ Inhibin } \\
\hline & Inhibin & $\begin{array}{c}\text { Mean FSH } \\
\text { concentration }\end{array}$ & $\begin{array}{c}\text { FSH receptor } \\
\text { binding per testis }\end{array}$ & Testosterone & $\begin{array}{c}\text { Mean FSH } \\
\text { concentration }\end{array}$ & $\begin{array}{c}\text { FSH receptor } \\
\text { binding per testis }\end{array}$ \\
\hline Group 1 & $0.73 * *$ & -0.23 & $0.74 * *$ & $0.69 * *$ & 0.15 & $0.71^{* *}$ \\
\hline Group 2 & $0.56^{*}$ & -0.42 & $0.69^{* *}$ & $0.70^{* *}$ & -0.03 & $0.54 *$ \\
\hline
\end{tabular}

$* P<0.05$ and ${ }^{* *} P<0.01$ with 14 error $\mathrm{df}$.
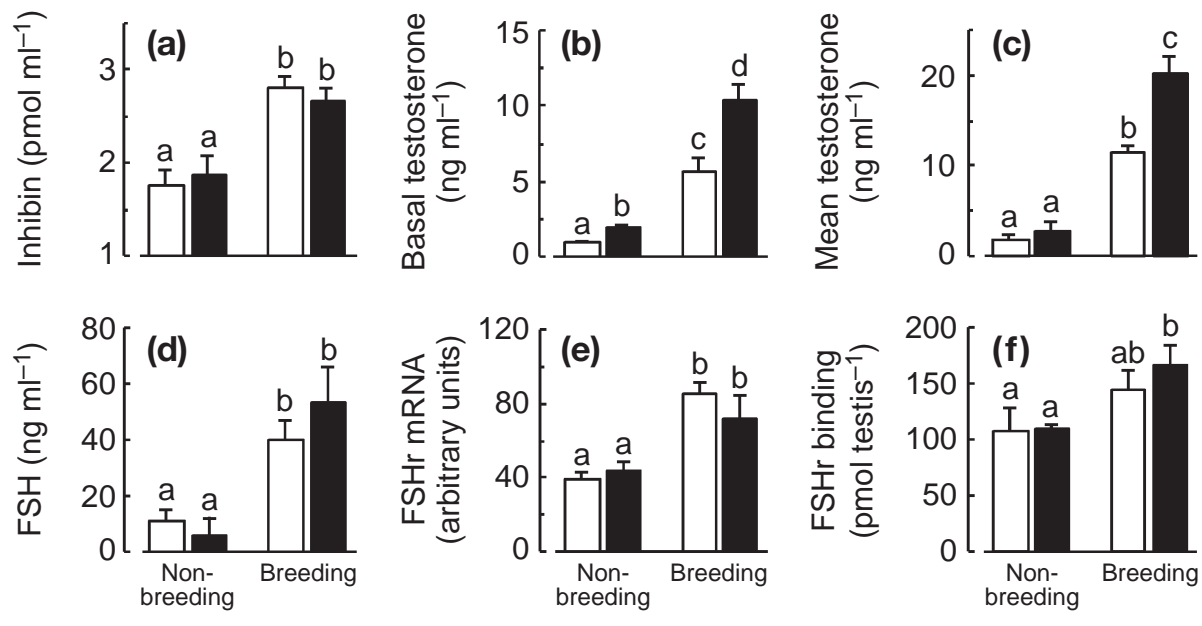

Season

Season

Season

Fig. 3. Mean serum concentrations of (a) immunoactive inhibin, (c) testosterone and (d) $\mathrm{FSH}$, (b) basal (interpulse) testosterone concentration, (e) testicular $\mathrm{FSH}$ receptor (FSHr) mRNA abundance and (f) FSH receptor binding per testis for control $(\square)$ and immunized rams $(\square)$ in the non-breeding (early April) and breeding (early September) seasons. Hormonal and testicular measurements were performed on days 21 and 23, respectively, of passive immunization of treated rams against oestradiol. Estimate of mRNA abundance was corrected for loading (pixel density of target probe divided by pixel density of $28 \mathrm{~S}$ rRNA probe) and is expressed relative to a control sample included in the blot. Values are mean $\pm \operatorname{SEM}(n=3$ (controls, nonbreeding

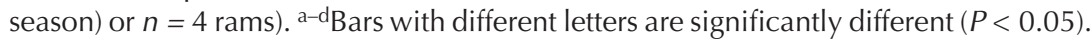

redeveloping stage (Fig. $2 \mathrm{~d}$ ), and either decreased $(P<0.05)$ to regressed values in the regressing stage (group 1) or to lower than regressed values in the redeveloped and regressing stages (group 2). FSH concentration was different $(P<0.05)$ between groups in these last two stages. When expressed on a per mg protein or per g tissue basis, FSH receptor binding activity in the testis did not differ significantly between groups or stages of the testicular cycle. However, values in the redeveloped stage did tend to be higher (approximately 20\%) than in the regressed stage, averaging $56.9 \pm 4.1 \mathrm{fmol} \mathrm{mg} \mathrm{protein}{ }^{-1}$ and $378 \pm 25 \mathrm{fmol}$ $\mathrm{g}$ tissue $^{-1}(n=8)$. On a per testis basis, FSH receptor binding was estimated to be $70 \%$ higher $(P<0.05)$ in the redeveloped stage than in the regressed stage (Fig. 2e). FSH binding either remained high (group 2) or was decreased slightly (group 1) in the regressing stage. Considering all four stages of the testicular cycle, inhibin concentration and testis size were correlated with $\mathrm{FSH}$ receptor binding per testis $(r=0.54-0.74, P<0.05)$ in both groups of rams (Table 2). Inhibin concentration was also related to testosterone concentration and testis size $(r=0.56-0.73, P<0.05)$.

\section{Experiment 2}

Passively immunizing rams against oestradiol for 3 weeks resulted in $75-100 \%$ increases $(P<0.05)$ in basal testosterone concentration in both the non-breeding and breeding seasons (Fig. 3b), and in mean testosterone concentration in the breeding season (Fig. 3c). Mean inhibin concentration was not influenced by immunization in either season (Fig. 3a), but was 50\% higher $(P<0.01)$ in rams in the breeding season; this increase was associated with a fivefold higher $(P<0.01)$ mean testosterone concentration (control rams). The seasonal increase in inhibin also 

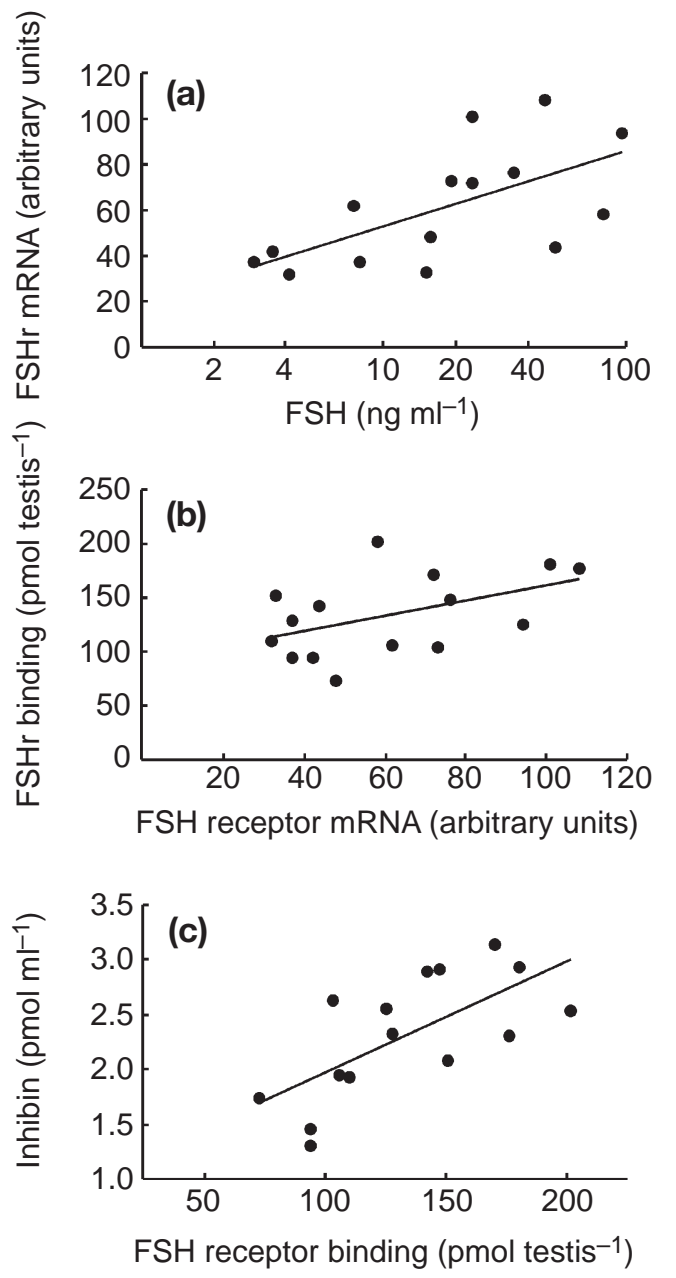

Fig. 4. Correlation between (a) serum FSH concentration and testicular FSH receptor (FSHr) mRNA abundance, (b) testicular FSH receptor mRNA abundance and $\mathrm{FSH}$ receptor binding per testis and (c) FSH receptor binding per testis and serum immunoactive inhibin concentration. (a) $r=0.62, P<0.05$; (b) $r=0.47, P<0.08$; and (c) $r=0.68, P<0.01$. $r$ values and probability values represent rams in both seasons $(n=15)$. Note the logarithmic scale for FSH concentration on the $x$ axis in (a).

corresponded to a near sixfold increase $(P<0.01)$ in mean FSH concentration (Fig. $3 \mathrm{~d}$ ) and a $45 \%$ increase $(P<0.01)$ in $\mathrm{FSH}$ receptor binding in the testis (Fig. 3f). Increased $\mathrm{FSH}$ binding per testis was mainly the result of a $30 \%$ increase $(P<0.05)$ in testicular mass from $293 \pm 22 \mathrm{~g}$ (non-breeding season, $n=7$ ) to $377 \pm 19 \mathrm{~g}$ (breeding season, $n=8$ ). FSH receptor binding activity expressed on a per $\mathrm{mg}$ protein or per $\mathrm{g}$ tissue basis was not significantly higher in the breeding season $\quad\left(83.6 \pm 5.8 \mathrm{fmol} \mathrm{mg} \mathrm{protein}^{-1}, \quad 418 \pm 30 \mathrm{fmol} \mathrm{g}\right.$ tissue $^{-1}$ ) than in the non-breeding season. The steady state mRNA abundance for FSH receptors was 90\% higher $(P<0.01)$ in the breeding season (Fig. 3e) and, as for blood FSH concentration and FSH binding in the testis, was not affected by immunization.

Taking rams in both seasons into account, FSH concen- tration $\left(\log _{10}\right)$ was related $(r=0.62, P<0.05)$ to mRNA abundance for $\mathrm{FSH}$ receptors in the testis (Fig. 4a). A weaker relationship $(r=0.47, P<0.08)$ was observed between abundance of FSH receptor mRNA and $\mathrm{FSH}$ binding per testis (Fig. 4b). FSH receptor binding per testis was correlated to a greater extent $(r=0.68, P<0.01)$ with inhibin concentration (Fig. 4c).

\section{Discussion}

The regulation of inhibin secretion in seasonally breeding rams is not well understood. In particular, the relative roles of blood FSH and testosterone concentrations, and the number of FSH receptors in the testis, are unknown. In the present study, novel experiments are described which indicate that changes in FSH secretion and in numbers of $\mathrm{FSH}$ receptors per se regulate secretion of immunoactive inhibin during the seasonal testicular cycle of adult DLS rams, and that $\mathrm{FSH}$ induces gene expression for its own functional, membrane-bound receptor late in recrudescence. The stronger FSH signals provided to Sertoli cells, first by increases in $\mathrm{FSH}$ concentration and then by increased FSH receptors, are critical regulators of inhibin given the sequential nature of the relationship between FSH and inhibin secretion during the testicular cycle. Furthermore, using a unique in vivo model that permits selective increases in testosterone concentration, the results of the present study provide evidence that testosterone is not a major determinant of secretion of immunoactive inhibin in rams.

Inhibin concentration in peripheral blood of rams typically increased during testicular recrudescence (Expt 1). As adult testes become fully active, Sertoli cells do not increase in number, but their capacity for protein secretion (for example, androgen binding protein and inhibin) and for supporting increased numbers of germ cells as spermatogenesis becomes more efficient, does increase (Hochereaude Reviers et al., 1987; Lincoln, 1989). The 'seasonal' increase in $\mathrm{FSH}$ in the rams under investigation co-ordinated with the increases in testicular size and inhibin, which were positively correlated with each other. A sequential relationship was noted, with FSH increasing a few weeks before scrotal circumference and inhibin. For both groups, scrotal circumference and inhibin were more highly correlated with FSH a month earlier than with concurrent FSH. In individual rams, FSH peaks generally preceded those in scrotal circumference (94\%) and inhibin (63\%). Later seasonal peaks and decreases in inhibin relative to $\mathrm{FSH}$ appear to be characteristic of adult rams of most breeds of sheep (Lincoln et al., 1990).

Although FSH participates in regulating developmental increases in inhibin secretion in rams, its exact role is uncertain. In an earlier study with adult DLS rams (Sanford et al., 1993), the magnitude (amplitude and duration) of the 'seasonal' FSH increase appeared to determine the magnitude of the corresponding inhibin increase, yet in the present investigation (Expt 1), increases in inhibin of smaller 
amplitude in group 2 than group 1 rams within each testicular cycle were not preceded by smaller increases in $\mathrm{FSH}$. Nonetheless, the results of the present study indicate that fluctuations in $\mathrm{FSH}$ concentration per se may regulate inhibin secretion in specific stages of the 'seasonal' testicular cycle. For example, increases in inhibin in group 1 rams in redevelopment were accompanied by increases in $\mathrm{FSH}$ concentration, but not in the number of $\mathrm{FSH}$ receptors in the testis. Furthermore, when the testes were redeveloped, FSH and inhibin concentrations were both lower in group 2 than in group 1 rams, although the number of testicular $\mathrm{FSH}$ receptors was just as high in each group. Precisely defining the temporal, causal relationship between these two hormones will probably require measurement of bioactive $\mathrm{FSH}$, as increases in inhibin in ram fetuses (Phillips et al., 1992) and pubertal ewe lambs (Padmanabhan et al., 1992) appear to be related more to bioactive than immunoactive $\mathrm{FSH}$ concentrations.

The ability of FSH to act on Sertoli cells in the testis of adult rats depends on the stage of the spermatogenic cycle within the seminiferous tubule. Differences in the extent of FSH stimulation between stages of the cycle are the result of differences in the number of FSH receptors present; expression of $\mathrm{FSH}$ receptors and concentrations of immunoactive and bioactive inhibin are all highest in stages XIII-III (Gnessi et al., 1997; Simoni et al., 1997). In the present study, the number of membrane-bound FSH receptors in the testes (number per Sertoli cell) of adult rams increased by an estimated $70 \%$ during recrudescence (Expt 1). Several experimental observations indicate that changes in $\mathrm{FSH}$ receptors per se during the 'seasonal' testicular cycle are central to $\mathrm{FSH}$ regulation of inhibin secretion. Firstly, inhibin concentration across the four stages of the 'seasonal' cycle was positively correlated with FSH receptor binding, but not with FSH concentration. Secondly, in group 1 rams, the increase in inhibin to peak concentrations as the testes completed redevelopment occurred as the number of FSH receptors continued to increase and $\mathrm{FSH}$ concentration began to decrease. Thirdly, although FSH concentrations in group 2 rams were lower than normal when the testes were fully redeveloped, the number of FSH receptors reached a maximum as usual and inhibin concentration remained relatively high. Although the evidence favours FSH and its cognate receptor system as a major modulator of inhibin secretion in rams, other controls may be just as important. In adult male mice made deficient in FSH receptors via targeted disruption of the FSH receptor gene, testicular content and blood concentration of inhibin are reduced by only 50\% (Dierich et al., 1998; Abel et al., 2000).

In addition to seasonal increases in FSH concentration and number of FSH receptors, an increase in the abundance of the mRNA encoding the FSH receptor gene was observed (Expt 2). These data support the assumption that in males of photoperiodic species (for example, rams, Djungarian hamsters and quail), testicular recrudescence is sustained by increases in the number of $\mathrm{FSH}$ receptors induced by parallel increases in FSH secretion (Barenton and Pelletier,
1983; Simoni et al., 1997). Although both the number of $\mathrm{FSH}$ receptors and abundance of $\mathrm{FSH}$ receptor mRNA increased during recrudescence, the values were not strongly correlated. This finding may be explained by the considerable turnover and recycling of membrane-bound receptors that occurs in Sertoli cells (Bardin et al., 1994), such that estimates of FSH binding reflect only functional receptors at the cell surface, not total receptor protein and, thus, product of extant mRNA. It should also be recognized that $\mathrm{FSH}$ binding was expressed per testis and accurately reflects the number of membrane receptors present per Sertoli cell, whereas mRNA was corrected for number of all (somatic and germ) cells. As testes redevelop, the number of Sertoli cells remains constant, but the number of germ cells increases significantly. This 'dilution' of Sertoli cells implies that the measured increase in mRNA content during testicular redevelopment was underestimated. Although our correlative results indicate that $\mathrm{FSH}$ upregulates its own receptor in rams, other factors such as paracrine interaction between germ cells and Sertoli cells are probably involved (Simoni et al., 1997), thereby influencing inhibin secretion and other FSH-dependent Sertoli cell functions. The most striking evidence for this in the present study is that the number of $\mathrm{FSH}$ receptors was normal in the redeveloped and regressing testes of group 2 rams (Expt 1), despite unusually low FSH secretion.

The possibility that testosterone is part of the paracrine system regulating inhibin secretion in rams was examined using passive immunization against oestradiol (Expt 2), enabling long-term, selective control of testosterone secretion under in vivo conditions (Sanford, 1987, 1989; Sanford et al., 1991). Low-level immunization for 3 weeks produced moderate increases in basal testosterone concentrations in both the non-breeding (1.0 $\mathrm{ng} \mathrm{ml}^{-1}$ ) and breeding (4.5 ng $\mathrm{ml}^{-1}$ ) seasons, and in mean testosterone concentration in the breeding season $\left(8.5 \mathrm{ng} \mathrm{ml}^{-1}\right)$. The amplitude of episodic testosterone secretion in immunized rams was nearly double that in controls (Price et al., 2000), probably contributing to the stronger testosterone signal, as Sertoli cells in ram testis appear to respond to individual androgen pulses (Monet-Kuntz and Terqui, 1985). Increases in testosterone concentration within the testes in the vicinity of androgen target cells would probably have been at least 30fold higher (Voglmayr et al., 1980; Tilbrook et al., 1991). As described by Price et al. (2000), increases in testosterone secretion in immunized rams were due in part to increased expression of steroidogenic acute regulatory protein (StAR) and entry of cholesterol into the steroidogenic pathway. Importantly, increases in testosterone secretion occurred independently of changes in $\mathrm{LH}$ and $\mathrm{FSH}$. Neither episodic $\mathrm{LH}$ release (Price et al., 2000) nor LH receptor binding per testis (for example, breeding season: control rams,

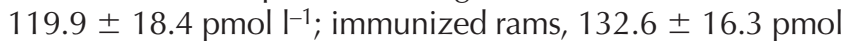
$\mathrm{I}^{-1}$; L. M. Sanford, D. G. Leggee and T. A. Yarney, unpublished) was affected by immunization. This finding should eliminate the possibility of any LH-induced paracrine effect of Leydig cells on inhibin secretion by 
Sertoli cells not mediated by testosterone (Bardin et al., 1989; Risbridger and de Kretser, 1989). Similarly, in keeping with our earlier studies, oestradiol immunization did not alter FSH secretion or the number of FSH receptors in the testis.

Circulatory concentrations of immunoactive inhibin in treated rams were not altered by the comparatively small increases in testosterone concentration when the testes were regressed (low FSH and inhibin) or by the more substantial increases in testosterone concentration when the testes were developed (high FSH and inhibin). These results are consistent with those of rat Sertoli cells in culture showing that testosterone does not influence basal or FSHstimulated immunoactive inhibin secretion (Bicsak et al., 1987; Toebosch et al., 1989; Lampa et al., 1999), although one study indicates that testosterone may suppress inhibin at low FSH concentrations (Morris et al., 1988). The absence of an effect of testosterone on immunoactive inhibin in rams, both in the short-term (Tilbrook et al., 1991) and long-term (present study), implies that the positive relationship between these two hormones during the seasonal testicular cycle is not causal. However, several investigators have suggested that testosterone may affect the secretion of bioactive inhibin (Steinberger, 1981; Verhoeven and Franchimont, 1983; Au et al., 1986), possibly by regulating post-transcriptional events involving the processing, assembly and glycosylation of the inhibin subunits (Toebosch et al., 1989). Whether the synthesis of inhibin A (or inhibin B) is modulated by testosterone in rams is not known.

In conclusion, this investigation provides new insights into the roles of $\mathrm{FSH}$ and testosterone in regulation of inhibin secretion during the seasonal testicular cycle of adult rams. Our experimental findings indicate that: (i) initial increases in immunoactive inhibin during testicular redevelopment are caused primarily by corresponding increases in FSH secretion, but that as development proceeds, FSH action is furthered by Sertoli cells acquiring additional FSH receptors; (ii) increases in functional, membrane-bound $\mathrm{FSH}$ receptors later in recrudescence are a result of $\mathrm{FSH}$ induction of gene expression for these receptors; and (iii) although $\mathrm{FSH}$ and its cognate receptor system play a central role, testosterone is at best a minor modulator of immunoactive inhibin secretion in rams, although the possibility of testosterone involvement in specific regulation of dimeric inhibin cannot be eliminated.

The authors would like to thank C. McFarlane, G. Rogers and C. Wilson for technical assistance and care of the rams, and B. Sutherland for veterinary assistance with gonadectomy of rams. Some of the materials used in the endocrine procedures were generously donated by: K. Cheng, University of Manitoba; J. Lussier, Université de Montréal; M. Sairam, Clinical Research Institute of Montreal; J. Vaughan, The Salk Institute; and the NIDDK. The authors are indebted to M. Fahmy, Agriculture and Agri-Food Canada, for providing the DLS rams. This research was funded by the Medical Research Council of Canada and the Natural Sciences and Engineering Research Council of Canada.

\section{References}

Abel MH, Wootton AN, Wilkins V, Huhtaniemi I, Knight PG and Charlton HM (2000) The effect of a null mutation in the follicle-stimulating hormone receptor gene on mouse reproduction Endocrinology 141 1795-1803

Albers N, Bettendorf M, Hart CS, Kaplan SL and Grumbach MM (1989) Hormone ontogeny in the ovine fetus. XXIII. Pulsatile administration of follicle-stimulating hormone stimulates inhibin production and decreases testosterone synthesis in the ovine fetal gonad Endocrinology 124 3089-3094

Al-Obaidi SAR, Bindon BM, Hillard MA and O'Shea T (1987) Reproductive characteristics of lambs actively immunized early in life with inhibinenriched preparations from follicular fluid of cows Journal of Reproduction and Fertility 81 403-414

Au CL, Irby DC, Robertson DM and de Kretser DM (1986) Effects of testosterone on testicular inhibin and fluid production in intact and hypophysectomized adult rats Journal of Reproduction and Fertility $\mathbf{7 6}$ 257-266

Bardin CW, Morris PL, Shaha C, Feng ZM, Rossi V, Vaughan J, Vale WW, VogImayr J and Chen C-LC (1989) Inhibin structure and function in the testis. In Regulation of Testicular Function: signaling molecules and cell-cell communication pp 10-23 Eds L Ewing and B Robaire. New York Academy of Sciences, New York

Bardin CW, Cheng CY, Mustow NA and Gunsalus GL (1994) The Sertoli cell. In The Physiology of Reproduction pp 1291-1333 Eds E Knobil and JD Neill. Raven Press, New York

Barenton B and Pelletier J (1983) Seasonal changes in testicular gonadotropin receptors and steroid content in the ram Endocrinology 112 1441-1446

Bicsak TA, Vale W, Vaughan J, Tucker EM, Cappel S and Hsueh AJ (1987) Hormonal regulation of inhibin production by cultured Sertoli cells Molecular and Cellular Endocrinology 49 211-217

Cheng KW, Simaraks S and Palmer WM (1981) Characterization of a radioimmunoassay for ovine $\mathrm{FSH}$ utilizing an anti-bovine $\mathrm{FSH}$ serum Journal of Reproduction and Fertility 61 115-121

Chong H, Pangas SA, Bernard DJ, Wang E, Gitch J, Chen W, Draper LB, Cox ET and Woodruff TK (2000) Structure and expression of a membrane component of the inhibin receptor system Endocrinology 141 2600-2607

Dierich A, Sairam MR, Monaco L, Fimia GM, Gansmuller A, LeMeur M and Sassone-Corsi P (1998) Impairing follicle-stimulating hormone (FSH) signaling in vivo: targeted disruption of the FSH receptor leads to aberrant gametogenesis and hormonal imbalance Proceedings National Academy of Sciences USA 9513 612-13 617

Fahmy MH and Shrestha JNB (1992) DLS and Arcott Sheep: new Canadian breeds Agriculture Canada Publication 1886/E

Gnessi L, Fabbri A and Spera G (1997) Gonadal peptides as mediators of development and functional control of the testis: an integrated system with hormones and local environment Endocrine Reviews 18 541-609

Hochereau-de Reviers MT, Monet-Kuntz C and Courot M (1987) Spermatogensis and Sertoli cell numbers and function in rams and bulls Journal of Reproduction and Fertility Supplement 34 101-114

Houde A, Lambert A, Saumande J, Silversides DW and Lussier JG (1994) Structure of the bovine follicle-stimulating hormone receptor complementary DNA and expression in bovine tissues Molecular Reproduction and Development 39 127-135

Illingworth PJ, Groome NP, Byrd W, Rainey WE, McNeilly AS, Mather JP and Bremner WJ (1996) Inhibin-B: a likely candidate for the physiologically important form of inhibin in men Journal of Clinical Endocrinology and Metabolism 81 1321-1325

Jarred RA, Cancilla B, Richards M, Groome NP, McNatty KP and Risbridger GP (1999) Differential localization of inhibin subunit proteins in the ovine testis during fetal gonadal development Endocrinology 140 979-986

Jin W, Wada S, Arai KY, Kishi H, Herath CB, Watanabe G, Suzuki AK, Groome NP and Taya K (2001) Testicular secretion of inhibin in the male golden hamster (Mesocricetus auratus). Journal of Andrology 22 207-211 
Knight TW (1977) Methods for the indirect estimation of testes weight and sperm numbers in Merino and Romney rams New Zealand Journal of Agricultural Research 20 291-296

Lampa J, Hoogerbrugge JW, Baarends WM, Stanton PG, Perryman KJ, Grootegoed JA and Robertson DM (1999) Follicle-stimulating hormone and testosterone stimulation of immature and mature Sertoli cells in vitro: inhibin and $\mathrm{N}$-cadherin levels and round spermatid binding Journal of Andrology 20 399-406

Lincoln GA (1989) Seasonal aspects of testicular function. In The Testis pp 329-385 Eds H Burger and D de Kretser. Raven Press, New York

Lincoln GA and McNeilly AS (1989) Inhibin concentrations in the peripheral blood of rams during a cycle in testicular activity induced by changes in photoperiod or treatment with melatonin Journal of Endocrinology 120 R9-R13

Lincoln GA, Lincoln CE and McNeilly AS (1990) Seasonal cycles in the blood plasma concentration of $\mathrm{FSH}$, inhibin and testosterone, and testicular size in rams of wild, feral and domesticated breeds of sheep Journal of Reproduction and Fertility 88 623-633

Lincoln GA, Clarke IJ and Sweeney T (1996) 'Hamster-like' cycles in testicular size in the absence of gonadotrophin secretion in HPD rams exposed to long-term changes in photoperiod and treatment with melatonin Journal of Neuroendocrinology 8 855-866

Lincoln GA, Townsend J and Jabbour HN (2001) Prolactin actions in the sheep testis: a test of the priming hypothesis Biology of Reproduction $\mathbf{6 5}$ 936-943

McKeown RM, O'Callaghan D, Roche JF and Boland MP (1997) Effect of immunization of rams against bovine inhibin $\alpha 1-26$ on semen characteristics, scrotal size, FSH, $\mathrm{LH}$ and testosterone concentrations Journal of Reproduction and Fertility 109 237-245

Miller S, Wongprasartsuk S, Young IR, McFarlane JR, de Kretser DM and Jenkin G (1997) Source of inhibin in ovine fetal plasma and amniotic fluid during late gestation: half-life of fetal inhibin Biology of Reproduction 57 347-353

Monet-Kuntz C and Terqui M (1985) Changes in intratesticular testosterone, cytoplasmic androgen receptors and ABP content of the ram testis after a single endogenous pulse of LH International Journal of Andrology 8 129-138

Monet-Kuntz C, Hochereau-de Reviers MT, Pisselet C, Perreau C, Fontaine I and Schanbacher BD (1988) Endocrine parameters, hormone receptors, and functions of the testicular interstitium and seminiferous epithelium in estradiol-immunized Ile-de-France rams Journal of Andrology 9 278-283

Morris PL, Vale WW, Cappel S and Bardin CW (1988) Inhibin production by primary Sertoli cell-enriched cultures: regulation by folliclestimulating hormone, androgens, and epidermal growth factor Endocrinology 122 717-725

Padmanabhan V, Mieher CD, Borondy M, I'Anson H, Wood RI, Landefeld TD, Foster DL and Beitens IZ (1992) Circulating bioactive folliclestimulating hormone and less acidic follicle-stimulating hormone isoforms increase during experimental induction of puberty in the female lamb Endocrinology 131 213-220

Paquette J (1993) Sexual Dimorphism in Prolactin Secretory Patterns and their Regulation by Estradiol in Adult Sheep MSc Thesis, McGill University

Phillips DJ, Smith PR, Heath DA, Condell LA and McNatty KP (1992) Bioactive and immunoreactive $\mathrm{FSH}$ and immunoreactive inhibin concentrations in the ovine fetus Journal of Endocrinology 134 287-295

Plant TM, Padmanabhan V, Ramaswamy S, McConnell DS, Winters SJ, Groome N, Midgley AR, Jr and McNeilly AS (1997) Circulating concentrations of dimeric inhibin $\mathrm{A}$ and $\mathrm{B}$ in the male rhesus monkey (Macaca mulatta). Journal of Clinical Endocrinology and Metabolism 82 2617-2621

Price CA, Cooke GM and Sanford LM (2000) Influence of season and lowlevel oestradiol immunoneutralization on episodic $\mathrm{LH}$ and testosterone secretion, and testicular steroidogenic enzymes and steroidogenic acute regulatory protein in the adult ram Journal of Reproduction and Fertility $118251-262$

Risbridger GP and de Kretser DM (1989) Paracrine regulation of the testis. In The Testis pp 255-268 Eds H Burger and D de Kretser. Raven Press, New York
Sairam MR, Chretien M and Li CH (1978) On the isolation of human pituitary hormones Journal of Clinical Endocrinology and Metabolism 47 1002-1008

Sambrook J, Fritsch EF and Maniatis T (1989) Molecular Cloning: A Laboratory Manual Cold Spring Harbor Laboratory Press, New York

Sanford LM (1985) Evidence that estrogen regulation of testosterone secretion in adult rams is mediated by both indirect (gonadotropin dependent) and direct (gonadotropin independent) means Journal of Andrology 6 306-314

Sanford LM (1987) Luteinizing hormone release in intact and castrate rams is altered with immunoneutralization of endogenous estradiol Canadian Journal of Physiology and Pharmacology 65 1442-1447

Sanford LM (1989) Increases in testosterone secretion in adult rams with immunoneutralization of endogenous estradiol occur in the absence of increases in pulsatile LH release or testicular LH receptors Acta Endocrinologica (Copenhagen) 120 180-186

Sanford LM and Robaire B (1990) Interaction of season and estradiol in the regulation of gonadotropin secretion in the ram Canadian Journal of Physiology and Pharmacology 68 150-156

Sanford LM, Leggee DG and Melnyk PM (1991) Maintaining a high physiological rate of testosterone secretion in the adult ram by estradiol immunoneutralization partially prevents testicular regression Canadian Journal of Animal Science 71 1099-1109

Sanford LM, Voglmayr JK, Vale WW and Robaire B (1993) Photoperiodmediated increases in serum concentrations of inhibin, folliclestimulating hormone, and luteinizing hormone are accentuated in adult shortened-scrotum rams without corresponding decreases in testosterone and estradiol Biology of Reproduction 49 365-373

Sanford LM, Moore C, VogImayr JK and Fahmy MH (2000) Sexual maturational changes in circulatory inhibin concentration in relation to FSH concentration and testicular size in Suffolk and DLS rams Theriogenology 54 719-730

Sar M, Hall SH, Wilson EM and French FS (1993) Androgen regulation of Sertoli cells. In The Sertoli Cell pp 509-516 Eds LD Russell and MD Griswold. Cache River Press, Clearwater, FL

SAS (1989) SAS/STAT User's Guide Version 6, Fourth Edition Statistical Analysis System Institute Inc., Cary

Schanbacher BD (1988) Radioimmunoassay of inhibin: serum responses to unilateral and bilateral orchidectomy Endocrinology 123 2323-2330

Schneyer AL, Sluss PM, Whitcomb RW, Martin KA, Sprengel R and Crowley Jr WF (1991) Precursors of $\alpha$-inhibin modulate folliclestimulating hormone receptor binding and biological activity Endocrinology 129 1987-1999

Simoni M, Gromoll J and Nieschlag E (1997) The follicle-stimulating hormone receptor: biochemistry, molecular biology, physiology, and pathophysiology Endocrine Reviews 18 739-773

Smith PK, Krohn RI, Hermanson GT et al. (1985) Measurement of protein using bicinchoninic acid Analytical Biochemistry 150 76-85

Squire RST, Greenwood JV and Sanford LM (1993) Usefulness of synthetic Mimetic ${ }^{\mathrm{TM}}$ ligands in establishing an affinity chromatography procedure for purifying estradiol antibody in sheep serum: potential application in regulating fertility of the ram Journal of Reproductive Immunology $\mathbf{2 3}$ $207-217$

Steel RGD and Torrie JH (1960) Principles and Procedures of Statistics McGraw-Hill Book Company Inc., New York

Steinberger A (1981) Regulation of inhibin secretion in the testis. In Intragonadal Regulation of Reproduction pp 283-298 Eds P Franchimont and CP Channing. Academic Press, London

Steinberger A, Janecki A and Jakubowiak A (1992) FSH actions on Sertoli cell secretions in stationary and superfused cultures. In Follicle Stimulating Hormone: Regulation of Secretion and Molecular Mechanisms of Action pp 217-230 Eds M Hunzicker-Dunn and NB Schwartz. Springer-Verlag, New York

Thomas GB, Davidson EJ, Engelhardt H, Baird DT, McNeilly AS and Brooks AN (1995) Expression of mRNA and immunocytochemical localization of inhibin $\alpha$ - and inhibin $\beta_{A^{-}}$subunits in the fetal sheep testis Journal of Endocrinology 145 35-42

Tilbrook AJ, de Kretser DM and Clarke IJ (1991) Studies on the testicular source of inhibin and its route of secretion in rams: failure of the Leydig 
cell to secrete inhibin in response to a human chorionic gonadotrophin/ LH stimulus Journal of Endocrinology 130 107-114

Tilbrook AJ, de Kretser DM and Clarke IJ (1999a) Changes in the suppressive effects of recombinant inhibin A on FSH secretion in ram lambs during sexual maturation: evidence for alterations in the clearance rate of inhibin Journal of Endocrinology 161 219-229

Tilbrook AJ, de Kretser DM and Clarke IJ (1999b) Seasonal changes in the negative feedback regulation of the secretion of the gonadotrophins by testosterone and inhibin in rams Journal of Endocrinology 160 155-167

Toebosch AMW, Robertson DM, Klaij IA, de Jong FH and Grootegoed JA (1989) Effects of FSH and testosterone on highly purified rat Sertoli cells: inhibin $\alpha$-subunit mRNA expression and inhibin secretion are enhanced by FSH but not by testosterone Journal of Endocrinology 122 757-762

Vale W, Rivier C, Hsueh A et al. (1988) Chemical and biological characterization of the inhibin family of protein hormones. In Recent Progress in Hormone Research pp 1-34 Ed. J Clark. Academic Press, New York

Vaughan JM, Rivier J, Corrigan AZ et al. (1989) Detection and purification of inhibin using antisera generated against synthetic peptide fragments. In Methods in Enzymology 588-617 Ed. PM Conn. Academic Press, Orlando

Verhoeven G and Franchimont P (1983) Regulation of inhibin secretion by Sertoli cell-enriched cultures Acta Endocrinologica 102 136-143
Voglmayr JK, Roberson C and Musto NA (1980) Comparison of androgen levels in ram rete testis fluid, testicular lymph and spermatic venous blood plasma: evidence for a regulatory mechanism in the seminiferous tubules Biology of Reproduction 23 29-39

Voglmayr JK, Jolley D, Vale W, Willoughby D, Moser A, So C-K, Chen C-L and Bardin CW (1992) Effects of follicle-stimulating hormone on inhibin release by different testicular compartments in the adult ram Biology of Reproduction 47 573-581

Woodruff TK, Besecke LM, Groome N, Draper LB, Schwartz NB and Weiss J (1996) Inhibin A and inhibin B are inversely correlated to follicle-stimulating hormone, yet are discordant during the follicular phase of the rat estrous cycle, and inhibin A is expressed in a sexually dimorphic manner Endocrinology 137 5463-5467

Yarney TA, Sanford LM and Sairam MR (1988) Sheep testicular gonadotropin binding sites: characterization and changes with surgical shortening of the scrotum Canadian Journal of Physiology and Pharmacology 66 1319-1327

Received 25 June 2001

First decision 21 August 2001.

Accepted 25 October 2001. 